\title{
RECONSTRUCTION OF NEGRELLI'S VIADUCT FROM A GEOTECHNICAL ENGINEERING POINT OF VIEW
}

\author{
LINDA ČERNÁ VydROVÁa, \\ ${ }^{a}$ Czech Technical University in Prague, Faculty of Civil Engineering, Department of Geotechnics, Thákurova 7 , \\ 16629 Prague, Czech Republic \\ ${ }^{b}$ HOCHTIEF, a. s., Division Traffic Infrastructure, Plzeňská 16, 15000 Prague, Czech Republic \\ correspondence: linda.cernavydrova@hochtief.cz
}

ABSTRACT. The reconstruction project deals with the unsatisfactory condition of the bridge construction, involving the railway superstructure with its signalling, communication and power equipment as well as the overhead lines all in an integrated manner. The article presents the contractor's view of this unique project and the initial experience gained during the first year of the construction. Emphasis is laid on geological conditions and on geotechnics, especially as they relate to work on the special foundation which constitute a significant part of the reconstruction.

KEYWORDs: Negrelli's Viaduct, bridge structure, subsoil, load capacity of arches, repair, special foundation.

\section{BASIC BACKGROUND InFORMATION ON THE PROJECT}

The owner builder is Správa železniční dopravní cesty, státní organizace (The Railway Infrastructure Administration Authority, a state organization). The funding is provided by the Connecting Europe Facility (CEF) programme of the EU; the project is co-funded at the national level by Státní fond dopravní infrastruktury (The State Fund for Transport Infrastructure). The general designer is the company SUDOP PRAHA a. s. Reconstruction of the bridge is performed by a joint venture of the companies HOCHTIEF CZ a. s. (Division of Traffic Infrastructure,), STRABAG Rail a. s. and AVERS, s. r. o. The construction work has been carried out during a complete closure of the railway on the bridge starting July 2017. The railway traffic will be resumed in January 2020. The finishing work will continue until June 2020. Reconstruction of the Negrelli's Viaduct (Figure 1) is closely linked to the planned construction project named Upgrade of Railway Line Praha-Kladno, which the viaduct reconstruction will make possible in the future [1 3].

\section{Brief Description of the PROJECT}

The Negrelli's Viaduct is situated on the railway track section Praha Masarykovo nádraží - Praha Bubny that forms part of the railway line from Praha Masarykovo nádraží to Děčín hl. n. (route segment 0801) and Praha Masarykovo nádraží Hrabovka Praha Masarykovo nádraží Karlín (route segment 1505). It was opened to rail transport in May 1850. In 1875 , it was extended by a "connecting viaduct" for the railway line Hrabovka - Karlín. Both these parts of the railway line are integrated in a countrywide railway network owned by the Czech Republic,

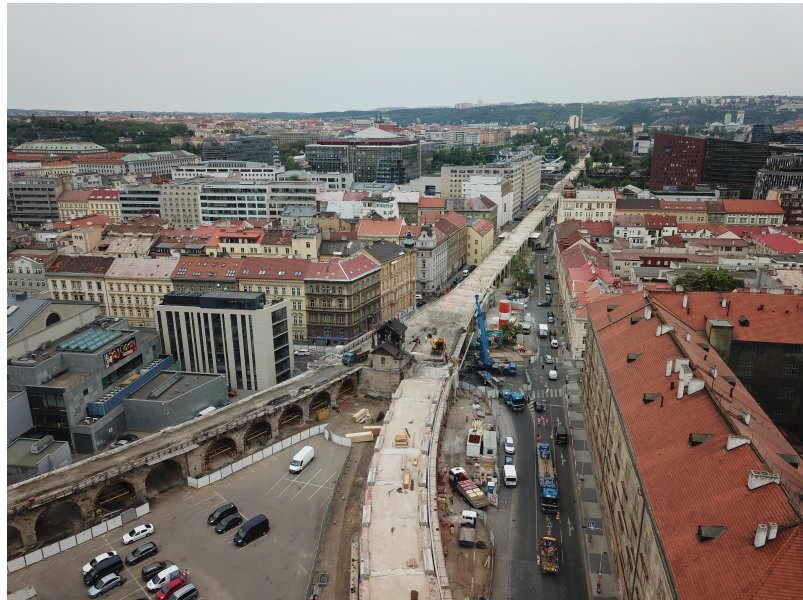

Figure 1. Bird's-eye view of the Negrelli's Viaduct during the reconstruction.

represented by Správa železniční dopravní cesty, s. o. (The Railway Infrastructure Administration Authority); the rail transport operator is České dráhy, a. s. (Czech Railways). The bridge, together with the signal box no. 249 is on the list of cultural heritage buildings [1].

\section{Purpose and preparation of THE RECONSTRUCTION}

The main reason for the reconstruction of the bridge was the poor technical condition of the arches, see Figure 2 Due to defects in the waterproofing and drainage systems that resulted in water leaks into the structure, the arches have suffered a number of flaws and thus required repairs of the masonry or replacement of the masonry components. It has proved necessary to replace and renew the drainage system of the bridge, to strengthen the foundation of the selected 


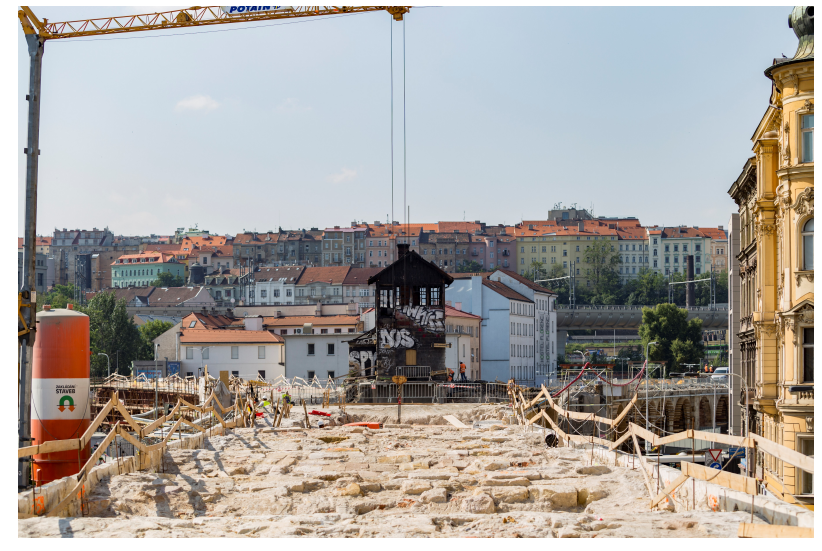

FiguRE 2. View of the exposed sandstone arches of the viaduct.

piers and to reinforce the masonry with grouting. In some cases, considering the extent of damage to the masonry, it is necessary to dismantle the arches completely, to replace the worn-out stone blocks by new ones and then to re-mason the arches and the piers as well, if this also is necessary.

The purpose of the project is to ensure that the obligatory parameters that apply to upgraded railway lines will be met. That means, in particular, the structure clearance GC, the load capacity class D4, adjustments of the track geometry to remove the local speed limits to secure adequate capacity of the railroad, also to comply with the health limits regarding noise and vibrations, and to replace the inadequate structures and equipment.

\section{Geological and Geotechnichl CONDITIONS}

The location in question is at the alluvial plain of the Vltava River. The terrain has been affected by anthropogenic activity to the maximum extent. It is an area that used to be behind the historic walls of the city of Prague. On the right bank, there were three tributaries of the Vltava River, but these are now filled up. The ground has been shaped by embankments that are up $6 \mathrm{~m}$ thick. The bedrock is made up of rocks from the Prague Ordovician period. On the right bank of the Vltava River, there are the Šárka and Bohdalec formations that turn into the Záhořany formations in approaching the Vltava River.

Northward, at the island Rohanský ostrov, the bedrock changes to the Vinice formation. Underneath the riverbed, there are also Letná formations. All these formations belong to the upper Paleozoic Era, the Beroun phase. These formations can be characterized as a sequence of furrowed dark grey siltites, silty shales, clay shales and clay stones.

The superincumbent formations in the given area are represented especially by the typical Pleistocene fluvial sediment drifts covered by Holocene alluvia and fills. The terraced sediments of the Vltava River consist of sands with clay. At deeper levels, the sediments are substituted by sands and gravel sands. At the base, the sediment is often of coarse gravel or boulder [1+3].

\subsection{HydrogeologicAl CONDITIONS}

The occurrence of groundwater in the given location is associated particularly with sand and gravel sand terraced areas that are porous and easily permeable. In those, a continuous groundwater level is created, the depth of which depends on the water level of the Vltava River. The Ordovician rock bed is poor in the groundwater. The unweathered shales are not very permeable; if weathered, they have the nature of clay soil that is not easily permeable. The groundwater in the Ordovician shales has a predominantly sulphate aggressivity and the highest degree of aggressivity is in the Bohdalec formation [1].

\subsection{TeCtonic COnditions}

At the place where Negrelli's Viaduct starts (on the Karlín side at the foot of the Vítkov hill), there is a significant tectonic line - the Prague fault. This tectonic fracture causes a substantial decrease in the strength of the adjacent rocks. The Prague fault is on the north side merging with a massive fault zone. It exists as a wide zone of fractures consisting of a number of parallel faults [1].

\section{Brief Description of the RECONSTRUCTION}

Even though large-scale surveys were carried out, it was not possible to rule out beforehand that after having removed the upper courses on the stonework, and having exposed the underside of the arches, or even after the areas not accessible at the time of preparation of the design would have been made accessible, so that it would then have to be decided - during the actual construction itself - in favour of a change in the extent of the repair works, replacement of the stones or indeed rebuilding the arches.

The viaduct is reconstructed in its entire length, which is $1,413 \mathrm{~m}$. All 100 arches will be repaired. 8 of them span over two tributaries of the Vltava River, 5 bridge structures run across roads, 2 bridge structures that were built later will be replaced and 14 arches completely rebuilt. A strict and clear number coding system has been created for the stones (applied in photogrammetric measuring), which facilitates an unmistakable identification of the stones even if they have to be dismantled and then placed back into the arches.

Given the fact that the bridge is on the list of cultural heritage buildings, a restoration survey and detailed diagnostics of the individual stonemasonry components represent almost a third of the total scope of the work. Based on the diagnosis, there is then a decision on the further method and progress of the repair works. 
At the beginning of the reconstruction, the built-in structures and extensions of the bridge were removed. Further, the railway superstructure was taken down, the overhead lines removed and the track ballast excavated. On the supporting brackets on the side of bridge or on the cable trays, a $22 \mathrm{kV}$ power cable of PREdi a. s. was temporarily suspended - it had been installed on the bridge but had impeded the work to be performed.

Contrary to the assumptions based on the design documents, no slab foundation was found. It had been substituted by a layer of gravel, which had to be removed, processed and placed back, to minimize the risk of point load on the arches when machines move on the bridge. Given the condition of the exposed piers, it was designed to grout the pier shafts in order to secure adequate load capacity and to eliminate the voids in the masonry. Further, the backfills in the arches have been removed, the arches exposed, a survey carried out and the underside of the arches repaired. Before that, the arches had to be propped with centerings on the underside. The undersides of the arches will then be waterproofed and the arches filled with pervious concrete. On the arch fills, a new reinforced concrete slab with an insulation system has been designed. The slab spreads the load onto the repaired arches. The parapet and handrails will be new. Installation of the railway superstructure will follow and so too will fitting of the railway equipment and placement of a raceway and other pipe sleeves into the track ballast. Then the overhead lines will be installed.

Concurrently with commencement of work on the deck, cleaning of the face sides of the arches from the ground level was started and the masonry components were diagnosed. Right after that, the subsoil was consolidated by jet grouting. In order to repair the substructure, in one bed of the Vltava River, double sheet pile caissons are being currently built. In the other riverbed, repair works to the pier shafts are underway - and due to the circumstances, there is required the assistance of divers. After a complete repair of the substructure, landscaping and finishing work will follow 1 3].

\section{Special Foundation Work at The END OF The $19^{\text {th }}$ CEntury}

Until the $19^{\text {th }}$ century, more substantial settlements of structures were prevented by founding the buildings on compressible soil on timber piles or more often, on horizontal timber grids or on a layer of sand no less than $1 \mathrm{~m}$ thick thus spreading the weight of a building over a larger area. Soft soil was also compacted by pole ramming. The massive piers of Negrelli's Viaduct were founded on robust timber grids or timber piles or right on the rock itself if the foundation bottom hit it.
The foundation of buildings in water was a tough challenge to surmount in the Middle Ages because the only way to pump water was to bring it out in buckets or to pump it using a treadwheel with buckets powered by humans or horses. It was not uncommon for this to engage 300 people, but it could hardly be a substitute for a contemporary $30 \mathrm{~kW}$ engine. For the caissons, sheet piles were used, and also balks of timber with a wedge-shaped point that was plated. A couple of those tips, sheet piles and piles were found during excavations of material from the future caissons. The sheet-pile walls also consisted of guide piles of a circular section bearing the ties. In between the ties, the individual sheet piles were then rammed. Due to unevenness of the timber and inaccuracy of the ramming, gaps were created between the sheet piles which were sealed with a tow and hard wedges.

Even though a willing and cheap labour force was available for the heavy manual work, for founding the piers of Negrelli's Viaduct, steam engines were used as well - in particular, to pump the water from the caissons. The steam engines were housed in wooden sheds and were connected with bucket pumps or screw pumps; each of them had a performance of about $12 \mathrm{k}$. In the press of these days it is mentioned that the steam engines could power also lime mills and rams. However, these were not conventional steam engines taking the form of a compact traction engine as known in later years. More specific information about these machines is unfortunately missing. The stones for the bridge construction were transported on the river; for their handling on the site, trolleys were used, which were operated manually 4 .

\section{Special Foundation Works}

\subsection{Grouting of the Pier Subsoil - Single-Phase Jet Grouting M1}

The selected piers were underpinned with jet grouted columns. The pilot bores through the existing foundation masonry of the bridge piers were driven using a full-face percussion rotary drilling method (submersible hammer) with a drill hole diameter of $150 \mathrm{~mm}$ with an air flush; a hydraulic drilling rig on a tracked undercarriage MSV 741/20 (producer: ZS, a. s.) and a compressor Atlas Copco XAHS were also used, as depicted in Figure 3.

The drill holes for the TI columns and the subsequent TI M1 (ascending method) were driven using a full-face rotary drilling method with a drill hole diameter of $140 \mathrm{~mm}$ to $185 \mathrm{~mm}$ and with a combination of water and cement flush. Hydraulic drilling rigs were used - HBM 12K/Hy-ZS (producer: Hausherr, Germany, and customized by ZS, a. s.) and a drilling rig Jano HVS 482 on a tracked undercarriage and in confined spaces, a hydraulic drilling rig on a tracked undercarriage MSV 741/20. The grout was produced at an automated production centre TWM 30 , the cement was batched from a pressure container 


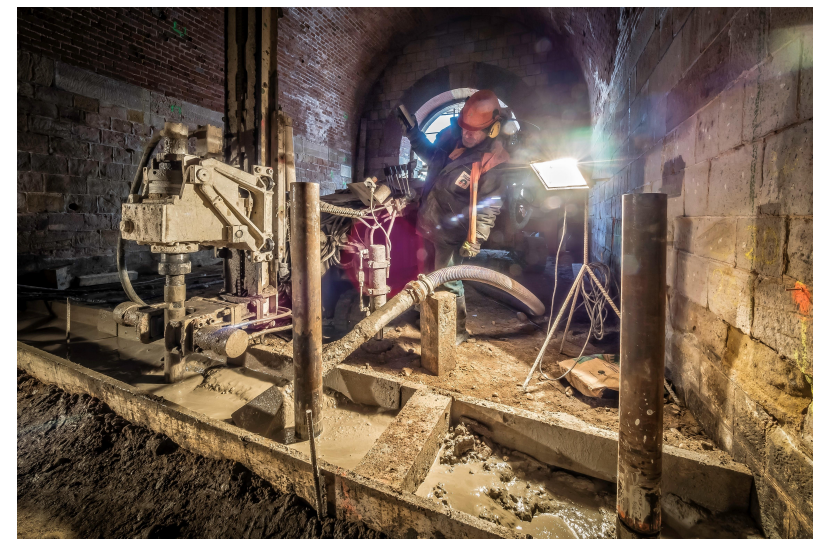

FiguRE 3. Special foundation works at the former custom house.

$56 \mathrm{~m}^{3}$. For TI M1, a high-pressure pump TW 600 was used [5].

\subsection{Conventional Grouting of the Pier SHAFTS}

With respect to the expected porosity of the pier fillings, in order to increase their load capacity, lowpressure grouting was designed. The drill holes for fitting a PVC bushing were driven using a double rotary drilling method with a drill hole diameter of $203 \mathrm{~mm}$ with an air flush; a hydraulic drilling rig on a tracked undercarriage Jano-7 HVS 6187 and HBR 504 FTW and a compressor Atlas Copco XRVS were used.

The drill holes for the grouting were driven using a full-face percussion rotary drilling method (submersible hammer) with a drill hole diameter of $125 \mathrm{~mm}$ to $152 \mathrm{~mm}$ with an air flush. A hydraulic drilling rig on a tracked undercarriage Jano-7 HVS 6187 and HBR 504 FTW and a compressor Atlas Copco XRVS were used. For dust control during the drilling, a foam deduster was used. For the grouting, an injection pump Haponic 4/52, an activation mixer AKC 025 and a mixer truck DM 025 were all used. An injection level in a drill hole was defined with a simple expandable oburator ring.

\subsection{Grounding Micropiles}

In the selected piers, grounding micropiles were installed. The drill holes for the micropiles were driven using a double rotary drilling method with a drill hole diameter of $140 \mathrm{~mm}$ to $185 \mathrm{~mm}$ with an air flush. A hydraulic drilling rig on a tracked undercarriage Jano-7 HVS 6187 and HBR 504 FTW and a compressor Atlas Copco XRVS were used. For dust control during the drilling, a foam de-duster was used. For the grouting, an injection pump Haponic 4/52, an activation mixer AKC 025 and a mixer truck DM 025 were all used. The injection levels were defined in the steel rod of the micropiles using a double expandable oburator ring.

\subsection{Principle of the Designed Caissons}

The space around the piers that was needed for their repair was designed to be supported by building double sheet pile caissons. Since the caissons are quite narrow in relation to their depth of 5.0 to $5.6 \mathrm{~m}$, spacing of the sheet piles is $2.2 \mathrm{~m}$ and the caissons are, at the crest, rested on the pier masonry. The maximum excavation along a pier is to the rock bed level, which is in practical terms to the sheet pile footing.

The caisson structure consists of two parallel sheet pile walls cross-connected with rods. The spacing of the rods leading from the bottom level to the crest of the opposite wall is, in the case of the outside wall, $2.4 \mathrm{~m}$ and in the case of the inner wall to be excavated to the footing, $1.2 \mathrm{~m}$. The inner sheet pile wall footing is moreover supported with tie bars driven into the rock bed at a spacing of $1.2 \mathrm{~m}$. The space between the sheet piles is filled up. To prevent water leaks under the sheet pile footings in case the footing is not embedded in the impermeable bed, e.g. if the rock bed surface is not even, or if there are boulders at the gravel base, every other sheet pile of the water-facing wall is fitted with an injection pipe allowing additional sealing.

In order that the drilling rig could travel to the caisson crest level, it was designed to widen the crest towards the pier along the inner sheet pile wall by about $130 \mathrm{~cm}$. The platform consists of two sheet piles fitted on steel braces.

\section{Conclusion}

The location of the viaduct has been often criticized since the end of the $19^{t h}$ century when this railway construction became an obstacle to traffic as the city developed. It has also been viewed as an unwelcome intervention into the city space, suggesting that the whole route should have been designed much more to the east. At the time of the construction, however, the cheap land in the countryside were the most convenient for the railway and this fact influenced the location of the viaduct and its route. Just like the construction itself, its designer was not duly appreciated at the time either. This is readily apparent from the name of the bridge as well - for a hundred years it was called generally "viaduct of Společnost státní dráhy" i.e. State Railway Company or later "the railway viaduct from Karlín to Holešovice".

It was named after its creator only from the 1950s. To this day, the construction is regarded by Prague citizens as a hideous and bothersome structure that, in spite of all reconstructions and subsequent enlargements for a lighter easement, still complicates traffic conditions. Hardly anyone realizes how old this bridge structure really is-and how beautiful it is. Last but not least, thanks to the reconstruction, a significant cultural heritage transport engineering building will be preserved. 


\section{REFERENCES}

[1] SUDOP. Sudop Praha, a. s., Rekonstrukce Negrelliho viaduktu, Doplňkový stavebně technický a IG průzkum (survey documents), Souhrnná zpráva (summary report). 07/2014.

[2] T. Martínek. Rekonstrukce Negrelliho viaduktu. In Proceedings of 23rd International Symposium MOSTY/BRIDGES 2018. Sekurkon, Brno, 2018.
[3] L. Černá Vydrová. Rekonstrukce Negrelliho viaduktu. Stavebnictví 8:32-38, 2018.

[4] P. Bažant. Metody zakládání staveb. Second printing. Academia, Československá akademie věd, 1973.

[5] Z. Bauer. Stavební stroje firmy Lanna. Corona, Prague, 2005. 